Relations industrielles

Industrial Relations

\title{
Claus OFFE : Contradictions of the Welfare State. Edited and introduced by John Keane, Cambridge, MIT Press, 1984, 310 pp., ISBN 0-262-65014-2
}

\section{Anthony Giles}

\section{Volume 41, numéro 3, 1986}

URI : https://id.erudit.org/iderudit/050246ar

DOI : https://doi.org/10.7202/050246ar

Aller au sommaire du numéro

\section{Éditeur(s)}

Département des relations industrielles de l'Université Laval

ISSN

0034-379X (imprimé)

1703-8138 (numérique)

Découvrir la revue

Citer ce compte rendu

Giles, A. (1986). Compte rendu de [Claus OFFE : Contradictions of the Welfare State. Edited and introduced by John Keane, Cambridge, MIT Press, 1984, 310 pp., ISBN 0-262-65014-2]. Relations industrielles / Industrial Relations, 41(3), 664-667. https://doi.org/10.7202/050246ar

Tous droits réservés (C) Département des relations industrielles de l'Université Laval, 1986
Ce document est protégé par la loi sur le droit d'auteur. L'utilisation des services d'Érudit (y compris la reproduction) est assujettie à sa politique d'utilisation que vous pouvez consulter en ligne.

https://apropos.erudit.org/fr/usagers/politique-dutilisation/ 
Japan becomes more and more the matter of the past, relevant as a relict, good for ornamental purposes, but pushed into the margin by the necesities of daily «modern» life.

With the cheapening of patriotism and religious beliefs there is a major danger that the gap will grow between the pretended japanese identity and the real, practical expediencyorientation of the people living in a mass society. The present day japanese practicism inclines people to pay homage to many gods at the same time. Japanese for the sake of good relations want to be everything at the same time: traditionalists, patriots, democrats, cosmopolitans, friends of the U.S. as well as of the U.S.S.R, religious, agnostic, committed, uncommitted.

This expedient relativism in the long run confuses primarily people who are trying hard to practice it. The moral-cultural dilemmas of modern Japan almost unavoidably have to multiply. The readers of the book by Alston have not been adequately prepared to grasp these dilemmas. There is a great need of a more critical writing about Japan. In the West we do not know enough about the nature of contradictions carried by people who undoubtably have great virtues but perhaps are in general too practical.

Alexander J. MATEJKO

University of Alberta

Contradictions of the Welfare State, by Claus Offe, edited and introduced by John Keane, Cambridge, MIT Press, 1984, 310 pp., ISBN 0-262-65014-2

Contradictions of the Welfare State is a collection of essays written over the past decade by Claus Offe. In his introduction, the editor surveys the major themes woven through the essays, and provides a critical appraisal of Offe's contribution to our understanding of the current crisis of the welfare state. The volume is concluded by an interview with offe, ranging over many of the issues discussed in the essays and highlighting some of the shifts in Offe's thinking.

At first glance it might seem that we stand to learn little about Canadian industrial relations from Offe. After all, the traditions of Anglo-American industrial relations research do not intersect in too many places with the disciplinary touchstones of Offe's work - Marxist economic analysis, critical theory, and modern socialist debates on the theory of the state. But a second glance behind the bright pink cover of this book reveals much that is of theoretical and practical relevance. Rather than detailing the contents of the individual essays, it will be useful to examine what we can learn from Offe.

Before looking more closely at what Offe has to offer, it should be pointed out that the title of the collection may be misleading to North Americans. We are accustomed to thinking about the welfare state in rather narrow terms - as the provision of assistance to those who are temporarily or permanently excluded from paid employment, and to those whose income is insufficient to provide 'basic necessities'. Offe's conception of the welfare state is much broader. Indeed, the various essays touch upon a wide variety of policy areas, including macroeconomic management, the regulation of industrial relations, labour market policy, social assistance, consumer policy, research and development policy, policing, and much else. A better description of his analytical target, then, is the modern interventionist state.

In fact, this is the first lesson that we can learn from Offse: that it is wrong to examine a single area of government policy in isolation from the multiple functions performed by the 
modern state, or from the broader political agenda underlying particular policies. When considering public policy, industrial relations specialists too often focus exclusively on laws relating directly to unions, collective bargaining and strikes, forgetting that such measures are only one small part of the broader array of policies which shape, and are shaped by, labourcapital relations. Offe's analysis of the political linkages between the emergence of Keynesian economic management and the erection of the post war structure of industrial relations policy facilitating unionization and collective bargaining (essay 8), as well as his discussion of the state's attempt to grapple with labour market problems (essay 3), are but two illustrations of the merits of a broader focus.

Taken as a whole, the essays in the book represent a consideration of the present crisis of the welfare state and of the political alternatives to which the crisis has given birth (or rebirth!). Throughout the book, theoretical reflection is blended with political analysis in a thoughtprovoking manner. Thus a recurrent theme is Offe's suggestion that neo-conservatives and socialists share the view that the welfare state is in crisis, and that their respective analyses of the crisis are marked by some curious similarities (essays 2 and 7 especially). This paradox provides Offe with a focus for exploring the conceptual propositions underlying different theories of the crisis. But this is not an arid or abstract excursion into the upper realms of theory, for his purpose is to evaluate the viability of contending political strategies. On this question Offe is unequivocal: the neo-conservative analysis of 'ungovernability' (or 'demand overload') is deeply flawed, and its solution, incarnated in Thatcherism and Reaganism, is therefore untenable.

Offe's powerful refutation of the neo-conservative programme hinges on a conceptual distinction dilemmas and contradictions. Whereas neo-conservatives portray the crisis as a set of resoluble dilemmas, Offe mounts a persuasive argument that the politico-economic system contains a number of ineradicable contradictions which produce unresoluble problems. This general thesis is the core of the book and is reiterated, in various forms, in nearly all of the essays. In essay 1 , for instance, Offe argues that the capitalist state is increasingly called upon to prop up the economic system (eg. through the provision of ever growing infrastructural needs), but that such increased intervention tends to siphon off resources for private investment; to continue on this path is therefore unrealistic, but a reversion to laissez-faire would be politically and economically disastrous. The argument is given a slightly different form in essay 8 where Offe argues that the principal mechanisms of the modern capitalist state - Keynesian welfare state policies and electoral competition between mass political parties - tend to stabilize capitalism in some areas at the same time as they generate instability in other areas. Keynesian social welfare policies dampen class conflict, but the fiscal and monetary measures required to do so tend to damage the investment climate and undercut work incentives; and, while mass parties succeed in squeezing radical demands from the electoral agenda, this is accomplished at the cost of promoting extra-parliamentary political conflict. More generally, Offe's central thesis is that the politico-economic systems of advanced capitalism contain fundamental contradictions which cannot easily be circumvented; thus, strategies of deregulation and the like are bound to create problems as severe as those which they address.

This brings us to a second feature of Offe's work from which we can learn. While his substantive conclusions are open to debate, his use of theory serves as an example of the potential fruitfulness of systems concepts. As used by industrial relations specialists, systems theory often amounts to little more than a diagramatic 'table of contents' of the subject matter of industrial relations. Offe, however, demonstrates that systems concepts can be mobilized to explore the substantive structures and dynamics of the system itself. Moreover, his stress on the tensions and contradictions which inevitably characterize all social systems is a refreshing con- 
trast to the orthodox conservative notion of systems as self-stabilizing mechanisms of conflict reduction. For this reason alone these essays (and essay 1 in particular) ought to be required reading for any industrial relations writer who claims to follow a systems approach.

At a substantive level, the theme which has the most relevance for industrial relations researchers is Offe's discussion of the labour market and the state's involvement therein. Of particular interest here is Offe's consideration of the implications of the commodity status of labour. While industrial relations researchers do not need to be reminded that capitalism is distinguished by the commodity status of labour, few will have considered the crucial role of the state in creating and sustaining the conditions of 'commodification' (property and employment law) or the state's efforts to cope with the problems of 'decommodification'. The notion of decommodification is especially useful in analyzing contemporary public policy. Briefly put, Offe argues that the stability of capitalism relies on the widespread commodification of values, but that there is an increasing tendency towards decommodification (ie. an overall decline in full-time paid employment in the private sector and a growing proportion of goods and services provided outside the market). From this angle, recent state policy - the extension of vocational education, retraining programmes, unemployment insurance, labour mobility schemes, etc. - can be viewed as a strategy of 'administrative recommodification', ie. an attempt by the state to sustain the centrality of the principle of exchange. These policies, however, must toe a fine line, for if the disciplinary function of the market is to be retained, then levels of extraemployment support cannot be so high that they function as disincentives. Further, politicoadministrative solutions to the problems of decommodification tend to erode the ideological basis of the 'free market economy'.

Now, while Offe's particular interpretation of these trends may be open to some debate, the broader relevance of his approach cannot be overlooked. To begin with, his analysis highlights the intimate connections between the state and the market, and in so doing opens up a series of little explored questions. Recent attempts by the Canadian government to adjust the labour market, for example, could be profitably examined from this perspective. More generally, his analysis throws into doubt the traditional image of the state as a 'neutral adjudicator' of social conflict, and encourages an exploration of the relationship between the exercise of power at the workplace and negotiating table on the one hand, and the distribution of political power on the other.

A final lesson which can be gleaned from this book stems from its political content. Offe's writing can be viewed as 'critical' in the best sense of the word, for it combines sophisticated academic analysis with open political expression. Too often we in industrial relations hide behind a facade of academic neutrality, offering 'technical' advice supposedly unblemished by political values. The danger of this technocratic non-partisanship is that 'values' are not thereby expunged, but merely hidden. Offe's example shows that we can come out of the political closet without leaving intellectual rigour behind on the hanger.

Contradictions of the Welfare State is not without flaws. Like all systems theorists, Offe sometimes portrays people as actors playing roles defined for them by a supra-human 'structure', a method which overlooks the very real scope for creative human agency. In places, oversimplifications detract from the analysis (as, for example, in his tendency to work from a twosector model of the economy). And, while Offe has elsewhere engaged in detailed empirical research, there is little evidence of that here except by way of the occasional illustration of abstract conjectures. Lastly, those who are unfamiliar with European political sociology should be warned that Offe's writing style is dense, and on occasion is nearly impenetrable. 
On balance, however, Canadian industrial relations specialists ought to dash out and buy this book. Undoubtedly they will find in it much with which to quarrel, but they will profit from the encounter.

Anthony GILES

University of New Brunswick

Group Process. An Introduction to Group Dynamics, by Joseph Luft, Alto, Cal.: Mayfield Publishing Company, 1984, XII + 237 pp., 3rd edition, ISBN 0-87484-542-4

Basic dilemmas are fundamental to all groups. They include such questions as: control of members but avoidance of group membership becoming inattractive to them, good communication between various levels without sacrificing the goal attainment, socialization without too much suppression of individual initiative, effective role playing but avoidance of formulization. However, general group problems have only a limited validity and more may be achieved by gaining awareness of cultural and existential conditioning of people within specific groups. Within the individualistically oriented civilization group is a coalition serving people who remain members as long as this suits them for a variety of reasons. Within collectivistically oriented civilizations people perceive their own destiny through the microcosm of their 'reference group' and act in the fulfilment of specific duties. Situations of imminent danger brings people more together than situations of safety, which allow us to ignore others and concentrate on our own immediate affairs.

The group experience, reduced to only one civilization and ignoring the existential conditioning of human behaviour, excludes a universal perspective. This is exactly the shortcoming of this book which is supposed to present group dynamics but identifies the latter with the U.S. middle class world. Group morale based on pleasing everybody remains at a much more superficial level than the morale of commited people ready willingly or unwillingly, to fulfill a task of a major existential importance: rescue somebody, achieve jointly something very important, etc. Conflicts based on personal malaccommodation are much different from the conflicts arising from a foreign civilizational affiliation or a deep ideological commitment, Luft in his book does not pay attention to these dimensions; he is perfectly satisfied with a unicivilizational perspective and reduces the small group problems to the US middle class trivialities. For example he claims that «all relationships are confidential, unless explicitly modified» (p. 27) without acknowledging that this is actually valid to some cultures, and in other cultures the opposite may be true.

Alexander J. MATEJKO

University of Alberta

Workplace Democratization. Its Internal Dynamics, by Paul Bernstein, New Brunswick, N.J., Transaction Books, 1983, 133 pp., ISBN 0-87855-711-3

The process of work democratization is a complicated enterprise in which the awareness of various interfering factors is of a great strategic importance. On the basis of a substantial case material, the author identifies the following crucial components: participation in decisionmaking (does there exist means for getting one's views frequently into decision-making bodies?), economic return to the participants based on the surplus they produce (are there any 